\title{
Analysis of Temperature Variability over Desert and Urban Areas of Northern China
}

Isaac Mugume ${ }^{1}$, Shuanghe Shen ${ }^{2}$, Sulin Tao ${ }^{2}$ and Godfrey Mujuni ${ }^{3}$

${ }^{1}$ Department of Geography, Geo informatics and Climatic Sciences, Makerere University, Uganda

${ }^{2}$ Collaborative Innovation Center on Forecast and Evaluation of Meteorological Disasters, Nanjing University of Information Science and Technology, China

${ }^{3}$ Department of Applied Meteorology, Data and Climate Services, Uganda National Meteorological Authority, Uganda

"Corresponding author: Shuanghe Shen, Collaborative Innovation Center on Forecast and Evaluation of Meteorological Disasters, Nanjing University of Information Science and Technology, China, Tel: +025-58731051; E-mail: yqzhr@nuist.edu.cn

Received date: Apr 03, 2016; Accepted date: Apr 19, 2016; Published date: Apr 27, 2016

Copyright: (c) 2016 Mugume I, et al. This is an open-access article distributed under the terms of the Creative Commons Attribution License, which permits unrestricted use, distribution, and reproduction in any medium, provided the original author and source are credited.

\begin{abstract}
Although many studies carried out have shown evidence of regional temperature variability along with global climate changes, it is important to compare the trends over different regions considering urbanization and levels of development. The study investigated temperature variability over urban and desert areas of Northern China using Mann-Kendall trend test, ranking temperatures and regression analysis for the data from 20 stations. The results show decreasing diurnal temperature range (DTR) over both deserts and cities in spring but decreasing (increasing) for cities (deserts) in summer (cities: $-0.140^{\circ} \mathrm{C} /$ decade and deserts: $0.068^{\circ} \mathrm{C} /$ decade). The DTR over cities is decreasing faster in spring over deserts (cities: $-0.307^{\circ} \mathrm{C} /$ decade, desert: $0.023^{\circ} \mathrm{C} / \mathrm{decade}$ ). The maximum temperature over desert areas is increasing at a higher rate (annual: $0.510^{\circ} \mathrm{C} /$ decade, spring: $0.540^{\circ} \mathrm{C} /$ decade and summer: $0.550^{\circ} \mathrm{C} /$ decade) than over cities (annual: $0.325^{\circ} \mathrm{C} /$ decade, spring: $0.252^{\circ} \mathrm{C} /$ decade and summer: $0.389^{\circ} \mathrm{C} /$ decade). The high temperature days and high temperature extremes for both areas are increasing while the frost days and low temperature extremes for both areas are decreasing. The spring minimum temperatures are also increasing over both areas and increasing at a higher rate over deserts $\left(0.536^{\circ} \mathrm{C} / \mathrm{decade}\right)$ than over cities $\left(0.529^{\circ} \mathrm{C} /\right.$ decade).
\end{abstract}

Keywords: Climate response; Mann-kendall trend test; Urban and desert areas of China

\section{Introduction}

The air temperature is one of the key parameters used in classification of climatological zones, for instance: temperate, humid, desert and semi-desert [1]. The variation of daily temperature is controlled mainly by incoming solar energy and outgoing long-wave surface radiation [2]. The air temperate does not vary in isolation and one of the cases is explained by Bryan et al. [3] of high temperatures and high pollution concentrations being associated with strength of high pressure systems and sunny (with fast photolysis rates) conditions.

Over a large area and over a long time, the temperatures can be averaged and thus assisting to describe the climate of area in terms of hotness/coldness. While weather elements vary from day to day or even place to place [4], climate too exhibits variability inter or intra season as well as inter or intra annual.

The changes in climate may manifest as changes in the mean state or in variability of their cycles [3]. Boko [5] illustrates these changes graphically as (Figures 1-3).

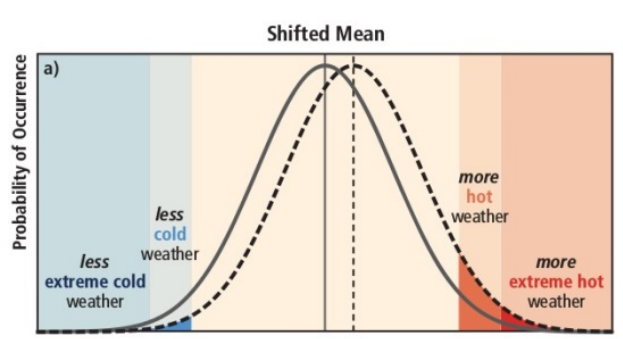

Figure 1: Shift in mean temperature.

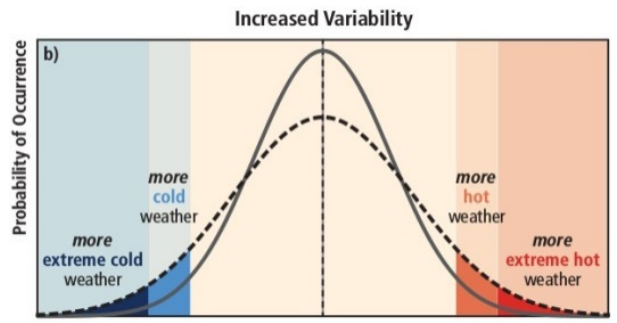

Figure 2: Change in temperature variability. 


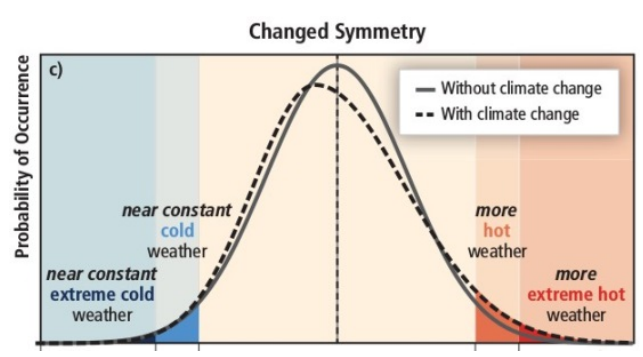

Figure 3: Change in symmetry distribution of temperature.

Climate change and variability has remained a research problem over the years. The previous studies demonstrated changes in precipitation, temperature, and other climatic parameters as well as vegetation cover [6] and these changes have been linked to economic development and urbanization [7]. Additionally, climate extremes have increased both in frequency and magnitude [8] but other areas have seen notable decline [9].

One of the indicators of climate change is changes in temperature and according to Roy et al. [10]; local temperature change is influenced by urbanization. A change in average temperature, can affect the amount of cloudiness as well as the type and amount of precipitation that Occurs [11] and is attributed to changes in radiative forcing $[8,12,13]$ such as changes in landscape leading to changes in surface reflectivity to solar radiation; surface moisture variability; modification of vegetation cover as well as anthropogenic heat release which combine and cause temperature rise.

The increase in temperature has impacts such as: increased incidence and severity of heat-waves, droughts $[13,14]$; shrinking of glaciers ice caps, mountain glaciers, and permafrost regions of the world [15] and can affect growing practices such as sowing dates and cultivars [16]. The global temperatures are estimated to have increased by $0.5-0.6^{\circ} \mathrm{C}$ over the last century $[9,13]$ and are estimated to increase by $0.3-0.7^{\circ} \mathrm{C}$ by 2035 [17].

Due to differential rates of development and urbanization as well as differences in land surface characteristics, we can expect different trends of temperature over deserts and cities. This is because, the economic development of a region is directly correlated with urbanization $[18,19]$ and urbanization affects surface greenness and leads to changes in surface albedo [12]. Thus these changes affect receipt of solar radiation on the earth and influence air temperature. Additionally urbanization and industrialization have led to increase in greenhouse gases (GHGs) which has also influenced temperature [20]. In recent years, China has experienced massive industrial growth and economic development as well as increased urbanization [21]. The growth of cities introduces the need for constant monitoring of weather and climate over different regions of China.

Although temperature trends have been studied in many regions of the world [17], studies considering differential responses of temperature over desert and cities are limited. We compare the temperature variability including their extremes over cities and desert areas of Northern China for the period 1981-2010. The study areas are presented in Figure 4; section 2 describes the data sources, section 3 presents the study methods, section 4 presents results and discussion while section 5 gives summary and conclusion.

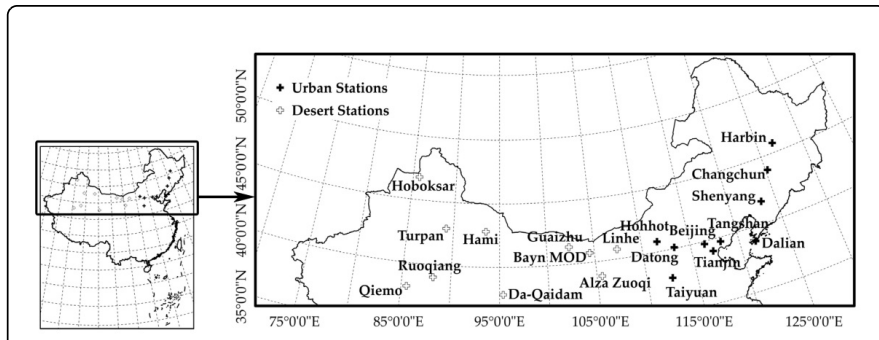

Figure 4: Map of China showing study region.

\section{Data}

The daily maximum and minimum temperature data is obtained from the School of Atmospheric Science of Nanjing University of Information Science and Technology (NUIST). This data is regularly updated and quality controlled to take care of the on-going research in the university. The data is then organized into temporal scales (annual, spring and summer). The diurnal temperature range (DTR) is computed from eqn. (1) as the difference between daily maximum temperature $\left(\mathrm{T}_{\max }\right)$ and daily minimum temperature $\left(\mathrm{T}_{\min }\right)$ and is also organized in terms of annual and seasonal temporal scales.

$\mathrm{DTR}=\mathrm{T}_{\max }-\mathrm{T}_{\min }$

The high temperature days are computed according to Thomas et al. [13] as days that have $\mathrm{T}_{\max }$ exceeding $32.0^{\circ} \mathrm{C}$ and the number of days with extreme high temperature is those that exceed 90th percentile of daily observed $\mathrm{T}_{\max }$. Our study used a higher threshold of $35.0^{\circ} \mathrm{C}$ for high temperature days and the number of days with extreme high temperatures as those with $\mathrm{T}_{\max }$ over the 95 th percentile. The extreme low temperature as those days with $\mathrm{T}_{\text {min }}$ below the 5 th percentiles of daily $\mathrm{T}_{\min }$ and the frost days as the days with $\mathrm{T}_{\min }$ below $0^{\circ} \mathrm{C}$.

\section{Methods}

In order to study the trends of temperature over regions of different climatology, the relative deficit and or surplus (anomalies) of temperature $\hat{T}$ are used and calculated using the eqn (2).

$$
\stackrel{\wedge}{T}=\frac{T_{i}-\bar{T}}{\bar{T}}
$$

Ti is temperature in question and $\bar{T}$ is respective long-term mean temperature over the study period. The $\bar{T}$ of a temperature data set, $\{\mathrm{T} 1, \mathrm{~T} 2, \cdots, \mathrm{Tn}\}$ is computed using eqn (3):

$$
\bar{T}=\frac{1}{n} \sum_{i=1}^{n} T_{i}
$$

\section{The Mann-Kendal trend test}

The Mann-Kendall (MK) trend test is used to analyze the trends of: $\mathrm{T}_{\max }, \mathrm{T}_{\min }$ and DTR. The MK is recommended by Qiang et al. [22] because it is (1) a rank-based nonparametric test, able to test trends without requiring normality or linearity; (2) less sensitive to outliers and (3) recommended by the World Meteorological Organization. Additionally Jagannathan and Parthasarathy [23] have identified the MK test as powerful for testing trends that are linear or non-linear. For 
Citation: Mugume I, Shen S, Tao S, Mujuni G (2016) Analysis of Temperature Variability over Desert and Urban Areas of Northern China. J

Page 3 of 9

a time ordered temperature data-set, we define MK trend test statistic, $\mathrm{S}$ (eqn. 4):

$$
s=\sum_{i=1}^{n-1} \sum_{j+i=1}^{n} \operatorname{sgn}\left(T_{j}-T_{i}\right)
$$

where $\operatorname{sgn}\left(\mathrm{T}_{\mathrm{j}}-\mathrm{T}_{\mathrm{i}}\right)$ is:

$$
\operatorname{sgn}\left(T_{j}-T_{i}\right)=\left\{\begin{array}{l}
+1: i f T_{j}-T_{i}>0 \\
0: \text { if }_{j}-T_{i}=0 \\
-1: i f T_{j}-T_{i}<0
\end{array}\right.
$$

for non-tied values of $T_{i}$, the variance $\delta^{2}(S)$ of the distribution of $S$ is computed using:

$$
\delta^{2}(s)=\frac{n(n-1)(2 n+5)}{18}
$$

for tied values of $\mathrm{T}_{\mathrm{i}}$, the variance is given by:

$$
\delta^{2}(s)=\frac{n(n-1)(2 n+5)-\sum t_{i}(i)(i-1)(2 i+5)}{18}
$$

$t_{i}$ is number of ties of extent $i$. The MK test statistic is then given by the standard Gaussian value, $\mathrm{M} \mathrm{K}_{\mathrm{z}}$ defined as:

$$
M K_{Z}=\left\{\begin{array}{l}
\frac{s-1}{\delta(s)}: \text { if } S>0 \\
0: \text { if } S=0 \\
\frac{s+1}{\delta(s)}: \text { if } S<0
\end{array}\right.
$$

\section{The computation of temperature extremes}

We use Jenkinson [24] formula (eqn. 9) for computing extreme temperatures. This formula is discussed by Chris and Anderson [25] in comparison with other formula for studying extremes and is recommended for the study of climate extremes [25,26]. According to the Jenkinson formula, the probability, $\mathrm{p}$ that a random value is less than or equal to the rank of that value, $\mathrm{T}_{\mathrm{i}}$ is given by:

$$
p=\frac{m-0.31}{n+0.38}
$$

where $\mathrm{m}$ is the position of the value and $\mathrm{n}$ is the number of values in the data set. The $T_{i}$ for example summer season which has 92 days, is arranged in ascending order: $\{\mathrm{T} 1, \mathrm{~T} 2, \ldots, \mathrm{T} 91, \mathrm{~T} 92\}$. The $\mathrm{T}_{\mathrm{i}}$ representing the 95th percentile is linearly interpolated between the 88th ranked value (giving: $\mathrm{p}=94.9 \%$ ) and 89 th ranked value $(\mathrm{p}=96.0 \%)$. The 95 th percentile is thus interpolated.

We considered high temperature days, frost days, high temperature extremes and low temperature extremes. The high temperature days are the days with $\mathrm{T}_{\max }$ greater than $35.0^{\circ} \mathrm{C}$, frost days are the days with $\mathrm{T}_{\text {min }}$ below $0^{\circ} \mathrm{C}$, high temperature extreme days are the number of days with $\mathrm{T}_{\max }$ over the 95th percentiles of daily $\mathrm{T}_{\max }$, while low temperature extreme days are the days with $\mathrm{T}_{\min }$ below the 5 th percentiles of daily $\mathrm{T}_{\min }$. The number of days with extreme high temperature and extreme low temperature are obtained using the Jenkinson formula (eqn. 9).

\section{Regression method}

We use regression to obtain the decadal (10 year) rate of changes of temperature, described as under. Given an $\mathrm{n}$ time-ordered temperature dataset: $\left\{T_{1}, T_{2}, \cdots, T_{n-1}, T_{n}\right\}$, ordered in time, $t$ the linear regression equation is given as:

$$
T_{i}=\alpha t_{i}+\epsilon
$$

where

$$
\mathrm{i}=1,2, \cdots, \mathrm{n}
$$

$\alpha$ is the rate of change, is the error and the decadal rate of change of temperature $\left(\alpha_{10}\right)$ is computed as:

$$
\alpha_{10}=\frac{T_{i+10^{-T}}}{10}
$$

\section{Results and Discussion}

\section{Annual temperature trends}

The annual temperature trends over deserts (Table 1) and over cities (Table 2) are obtained using $\mathrm{MK}_{\mathrm{z}}$ at $99 \%$ confidence level. Over deserts, we find an increasing trend for both $\mathrm{T}_{\max }\left(\mathrm{MK}_{\mathrm{z}}=0.431\right)$ and $\mathrm{T}_{\min }\left(\mathrm{MK}_{\mathrm{z}}=0.407\right)$ and a decreasing trend for DTR $\left(\mathrm{MK}_{\mathrm{z}}=-0.091\right)$. The annual DTR shows high variability (Figure 5). It peaked during the period 1990-2000 and declining over the period 2001-2010. This variability probably explains the weak decreasing trend in Table 1 . The annual trends of DTR for individual stations were in the range of: $-0.35^{\circ} \mathrm{C} /$ decade to $-0.04^{\circ} \mathrm{C} /$ decade. The $\mathrm{T}_{\max }$ has been increasing since 1985 (Figure 6) in the range of $0.36-0.70^{\circ} \mathrm{C} /$ decade and on average at $0.51^{\circ} \mathrm{C} /$ decade. The $\mathrm{T}_{\min }$ shows a high variable increasing trend (Figure 7 ) in the range of $0.06-0.8^{\circ} \mathrm{C} /$ decade and on average at $0.52^{\circ} \mathrm{C} /$ decade. This rate is slightly greater than that of $\mathrm{T}_{\max }$. We thus argue that $\mathrm{T}_{\min }$ increase faster than $\mathrm{T}_{\max }$ which could be accounting for the rate of decrease of DTR over deserts in (Table 1).

\begin{tabular}{|l|l|l|l|}
\hline Station & $\mathbf{T}_{\max }$ & $\mathbf{T}_{\min }$ & DTR \\
\hline Alza Zuoqi & 0.370 & 0.527 & -0.457 \\
\hline Bayn MOD & 0.448 & 0.037 & 0.269 \\
\hline Da-Qaidam & 0.591 & 0.497 & -0.067 \\
\hline Guaizhu & 0.301 & 0.467 & -0.223 \\
\hline Hami & 0.444 & 0.144 & 0.301 \\
\hline Hoboksar & 0.264 & 0.385 & -0.269 \\
\hline Linhe & 0.315 & 0.480 & -0.545 \\
\hline Qiemo & 0.522 & 0.406 & 0.278 \\
\hline Ruoqiang & 0.545 & 0.531 & 0.177 \\
\hline Turpan & 0.508 & 0.596 & -0.375 \\
\hline Average & 0.431 & 0.407 & -0.091 \\
\hline
\end{tabular}

Table 1: Annual temperature variation for desert areas.

\begin{tabular}{|l|l|l|l|}
\hline Station & $\mathbf{T}_{\max }$ & $\mathbf{T}_{\min }$ & DTR \\
\hline Beijing & 0.260 & 0.545 & -0.384 \\
\hline Changchun & 0.269 & 0.416 & -0.320 \\
\hline Dalian & 0.228 & 0.370 & -0.315 \\
\hline
\end{tabular}


Citation: Mugume I, Shen S, Tao S, Mujuni G (2016) Analysis of Temperature Variability over Desert and Urban Areas of Northern China. J

Page 4 of 9

\begin{tabular}{|l|l|l|l|}
\hline Datong & 0.402 & 0.554 & -0.292 \\
\hline Harbin & 0.260 & 0.582 & -0.683 \\
\hline Hohhot & 0.384 & 0.577 & -0.503 \\
\hline Shenyang & 0.140 & -0.145 & 0.214 \\
\hline Taiyuan & 0.407 & 0.697 & -0.393 \\
\hline Tangshan & 0.343 & 0.485 & -0.398 \\
\hline Tianjin & 0.214 & 0.016 & 0.145 \\
\hline Average & 0.291 & 0.410 & -0.293 \\
\hline
\end{tabular}

Over cities, we find both $\mathrm{T}_{\max }$ and $\mathrm{T}_{\min }$ increasing annually with exception of Shenyang and a decreasing DTR $\left(\mathrm{MK}_{\mathrm{z}}=-0.293\right)$. The annual DTR for cities decrease sharply (Figure 8 ) in the range of -0.659 to $-0.146^{\circ} \mathrm{C} /$ decade and on average $-0.238^{\circ} \mathrm{C} /$ decade. The $\mathrm{T}_{\max }$ is increasing (Figure 9) in the range of 0.11 to $0.501^{\circ} \mathrm{C} /$ decade and an average of $0.325^{\circ} \mathrm{C} /$ decade.

The $\mathrm{T}_{\min }$ (Figure 10) does not present plausible results but we can infer that $\mathrm{T}_{\min }$ was decreasing slightly over the period 1995-2010. With exception of Shenyang, the annual $\mathrm{T}_{\min }$ trends for individual stations were increasing in the range of 0.022 to $1.015^{\circ} \mathrm{C} /$ decade and an average of $0.566^{\circ} \mathrm{C} /$ decade. Thus the annual rate of increase of $\mathrm{T}_{\min }$ is greater than that of $\mathrm{T}_{\max }$ over cities.

Table 2: Annual temperature variation for cities.

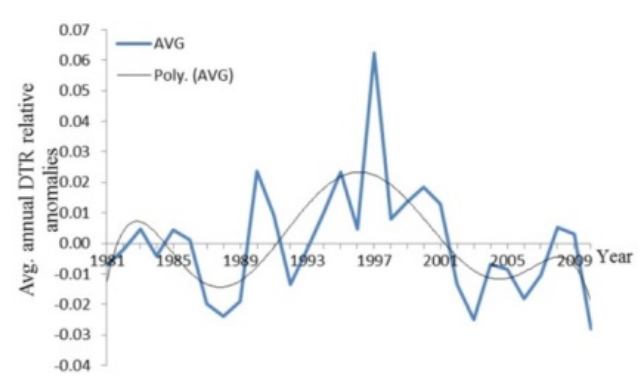

Figure 5: Annual DTR anomalies for selected desert areas.

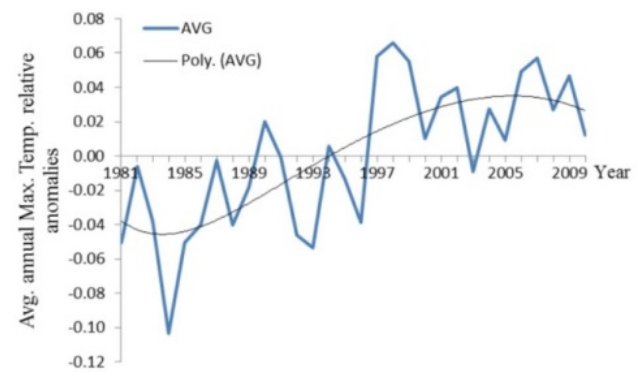

Figure 6: Annual maximum temperature anomalies for selected desert areas.

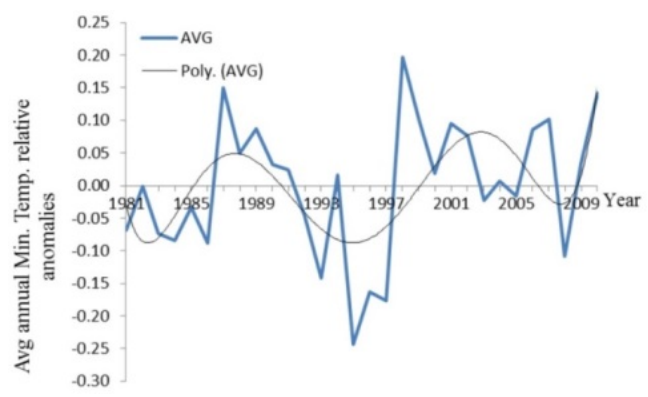

Figure 7: Annual minimum temperature anomalies for selected desert areas.

Figure 9: Annual maximum temperature anomalies for selected cities.

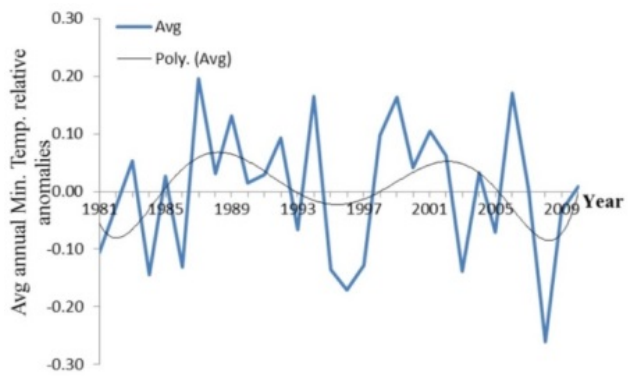

Figure 10: Annual minimum temperature anomalies for selected

cities.
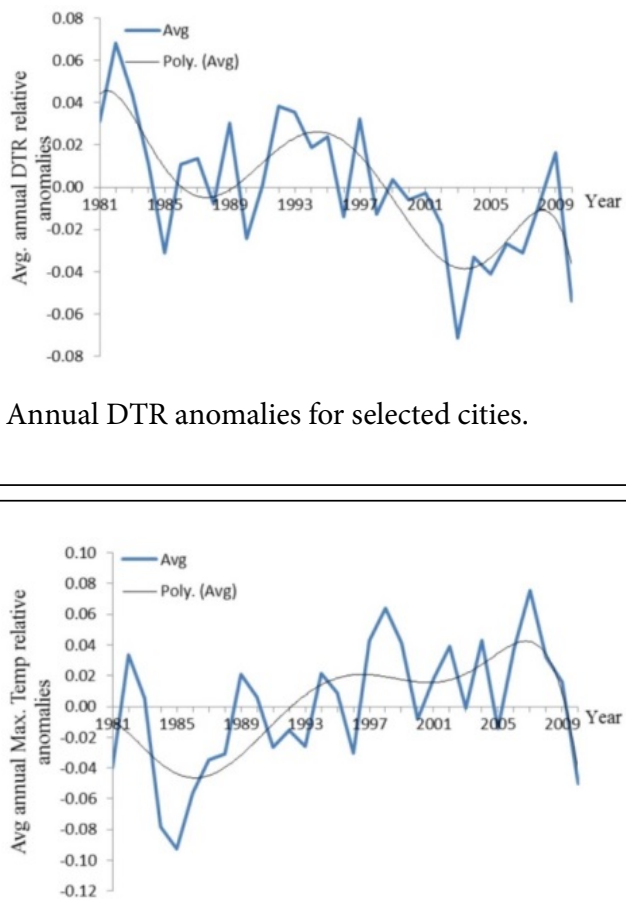

Figure 8: Annual DTR anomalies for selected cities. 
Citation: Mugume I, Shen S, Tao S, Mujuni G (2016) Analysis of Temperature Variability over Desert and Urban Areas of Northern China. J

Page 5 of 9

\section{Spring temperature trends}

The spring temperature trends over deserts (Table 3 ) and over cities (Table 4) are obtained using $\mathrm{MK}_{\mathrm{z}}$ at $99 \%$ confidence level.

\begin{tabular}{|l|l|l|l|}
\hline Station & $\mathbf{T}_{\max }$ & $\mathbf{T}_{\min }$ & $\mathbf{D T R}$ \\
\hline Alza Zuoqi & 0.274 & 0.416 & -0.218 \\
\hline Bayn MOD & 0.329 & 0.195 & 0.149 \\
\hline Da-Qaidam & 0.467 & 0.301 & 0.122 \\
\hline Guaizhu & 0.191 & 0.375 & -0.260 \\
\hline Hami & 0.255 & 0.269 & 0.113 \\
\hline Hoboksar & 0.149 & 0.324 & -0.209 \\
\hline Linhe & 0.195 & 0.499 & -0.370 \\
\hline Qiemo & 0.411 & 0.425 & 0.297 \\
\hline Ruoqiang & 0.343 & 0.508 & 0.090 \\
\hline Turpan & 0.177 & 0.425 & -0.209 \\
\hline Average & 0.279 & 0.374 & -0.050 \\
\hline
\end{tabular}

Table 3: Spring temperature variation for desert areas.

\begin{tabular}{|l|l|l|l|}
\hline Station & $\mathbf{T}_{\max }$ & $\mathbf{T}_{\min }$ & $\mathbf{D T R}$ \\
\hline Beijing & 0.154 & 0.338 & -0.195 \\
\hline Changchun & 0.113 & 0.264 & -0.278 \\
\hline Dalian & 0.214 & 0.320 & -0.175 \\
\hline Datong & 0.186 & 0.377 & -0.195 \\
\hline Harbin & -0.002 & 0.324 & -0.511 \\
\hline Hohhot & 0.246 & 0.457 & -0.297 \\
\hline Shenyang & 0.117 & -0.039 & 0.039 \\
\hline Taiyuan & 0.315 & 0.476 & -0.228 \\
\hline Tangshan & 0.163 & 0.384 & -0.338 \\
\hline Tianjin & 0.195 & 0.149 & 0.090 \\
\hline Average & 0.170 & 0.410 & -0.293 \\
\hline
\end{tabular}

Table 4: Spring temperature variation for cities.

Over deserts, we find both spring $\mathrm{T}_{\max }$ and $\mathrm{T}_{\min }$ increasing. The DTR over five stations is increasing while the rest are decreasing. On average, DTR is decreasing $\left(\mathrm{MK}_{\mathrm{z}}=-0.050\right)$ and it increased over the period 1990-2010 (Figure 11). Both $\mathrm{T}_{\max }$ (Figure 12) and $\mathrm{T}_{\min }$ (Figure 13) are increasing at $\mathrm{MK}_{\mathrm{z}}=0.279$ and $\mathrm{MK}_{\mathrm{z}}=0.374$ respectively and increased over the period 1987-2007. The differential increases in trends of $\mathrm{T}_{\max }$ and $\mathrm{T}_{\min }$, can in part explain the moderate increase of DTR over the same period. The rate of decrease of DTR of individual stations is in the range of -0.547 to $-0.18^{\circ} \mathrm{C} /$ decade except for the stations that presented an increasing DTR trend.

In general, the rate of decrease of DTR over $1981-2010$ is $-0.023^{\circ} \mathrm{C} /$ decade (negative sign is maintained to emphasize the decrease and differentiate it from increasing trend, where increase is shown with a positive sign). The spring $\mathrm{T}_{\max }$ is in general increasing in the range of $0.3-0.8^{\circ} \mathrm{C} /$ decade and on average at $0.54^{\circ} \mathrm{C} /$ decade. The spring $\mathrm{T}_{\text {min }}$, (Figure 13) is increasing too in range of $0.23-0.85^{\circ} \mathrm{C} /$ decade with an average of $0.56^{\circ} \mathrm{C} /$ decade.

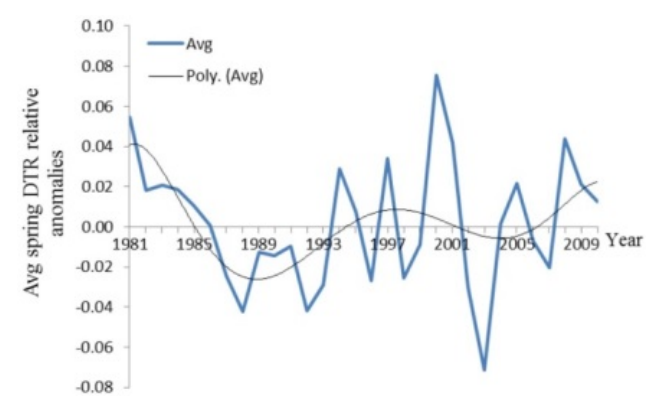

Figure 11: Spring DTR anomalies for selected desert areas.

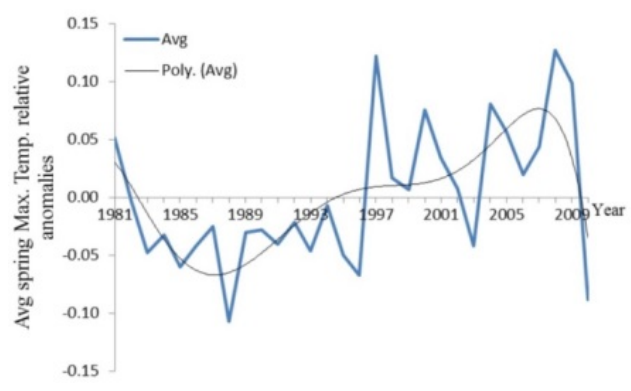

Figure 12: Spring maximum temperature anomalies for selected desert areas.

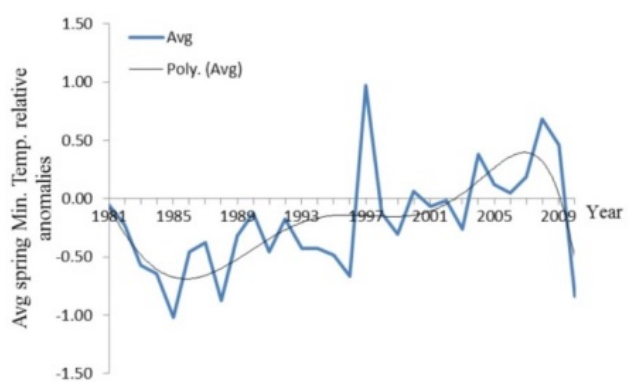

Figure 13: Spring minimum temperature anomalies for desert areas.

Over cities, we find an increasing trend of both spring $\mathrm{T}_{\max }$ and $\mathrm{T}_{\min }$ with exception of Harbin whose $\mathrm{T}_{\max }$ is decreasing and Shenyang's $\mathrm{T}_{\text {min }}$. The DTR is decreasing $\left(\mathrm{MK}_{\mathrm{z}}=-0.209\right)$ with the exception of Shenyang (Figure 14) in the range of -0.829 to $-0.157^{\circ} \mathrm{C} /$ decade and on average at $-0.307^{\circ} \mathrm{C} /$ decade. 
Citation: Mugume I, Shen S, Tao S, Mujuni G (2016) Analysis of Temperature Variability over Desert and Urban Areas of Northern China. J

Page 6 of 9

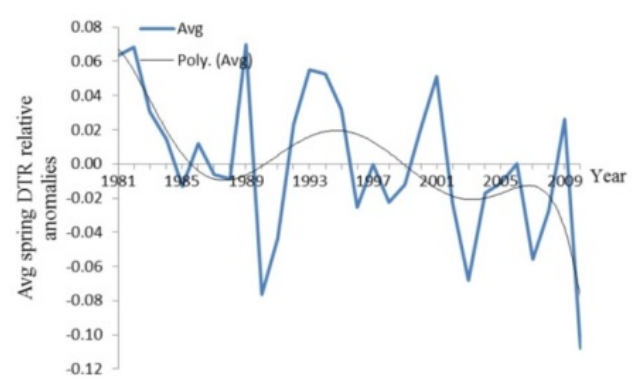

Figure 14: Spring DTR anomalies for selected cities.

The spring $\mathrm{T}_{\max }$ (Figure 15) is increasing with an average $\mathrm{MK}_{\mathrm{z}}$ of 0.170 and in the range of 0.052 to $0.533^{\circ} \mathrm{C} /$ decade and overall rate of $0.252^{\circ} \mathrm{C} /$ decade. The spring $\mathrm{T}_{\min }$ (Figure 16) is increasing as well with exception of Shenyang in the range of 0.137 to $0.928^{\circ} \mathrm{C} /$ decade and overall increasing at $0.560^{\circ} \mathrm{C} /$ decade.

The rate at which spring $\mathrm{T}_{\min }$ is increasing $\left(0.560^{\circ} \mathrm{C} /\right.$ decade $)$ is greater than the rate of spring $\mathrm{T}_{\max }\left(0.252^{\circ} \mathrm{C} /\right.$ decade $)$ which probably explains the decreasing trend of spring DTR $\left(-0.307^{\circ} \mathrm{C} /\right.$ decade $)$.

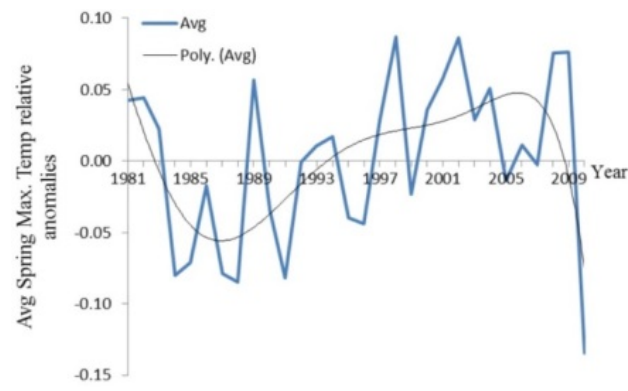

Figure 15: Spring maximum temperature anomalies for selected cities.

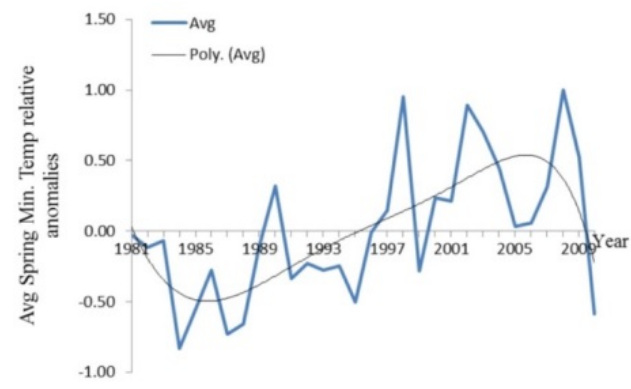

Figure 16: Spring minimum temperature anomalies for selected cities.

\section{Summer temperature trends}

The summer temperature trends over deserts (Table 5) and over cities (Table 6) are obtained using $\mathrm{MK}_{\mathrm{z}}$ at $99 \%$ confidence level.

\begin{tabular}{|l|l|l|l|}
\hline Station & $\mathbf{T}_{\max }$ & $\mathbf{T}_{\min }$ & DTR \\
\hline Alza Zuoqi & 0.287 & 0.444 & -0.301 \\
\hline Bayn MOD & 0.343 & 0.292 & 0.278 \\
\hline Da-Qaidam & 0.439 & 0.513 & -0.232 \\
\hline Guaizhu & 0.434 & 0.410 & 0.062 \\
\hline Hami & 0.485 & 0.195 & 0.315 \\
\hline Hoboksar & 0.324 & 0.434 & -0.090 \\
\hline Linhe & 0.278 & 0.526 & -0.315 \\
\hline Qiemo & 0.494 & 0.343 & 0.159 \\
\hline Ruoqiang & 0.522 & 0.462 & -0.039 \\
\hline Turpan & 0.499 & 0.333 & 0.163 \\
\hline Average & 0.411 & 0.395 & $-2.8 \times 10^{-18}$ \\
\hline
\end{tabular}

Table 5: Summer temperature variation for desert areas.

\begin{tabular}{|l|l|l|l|}
\hline Station & $\mathbf{T}_{\max }$ & $\mathbf{T}_{\min }$ & $\mathbf{D T R}$ \\
\hline Beijing & 0.228 & 0.494 & -0.255 \\
\hline Changchun & 0.287 & 0.352 & -0.136 \\
\hline Dalian & 0.085 & 0.186 & -0.145 \\
\hline Datong & 0.352 & 0.526 & -0.011 \\
\hline Harbin & 0.267 & 0.494 & -0.287 \\
\hline Hohhot & 0.324 & 0.536 & -0.067 \\
\hline Shenyang & 0.071 & -0.057 & 0.182 \\
\hline Taiyuan & 0.379 & 0.568 & -0.140 \\
\hline Tangshan & 0.237 & 0.384 & -0.329 \\
\hline Tianjin & 0.154 & 0.186 & 0.094 \\
\hline Average & 0.238 & 0.367 & -0.109 \\
\hline
\end{tabular}

Table 6: Summer temperature variation for cities.

Over deserts, the summer $\mathrm{T}_{\max }$ and $\mathrm{T}_{\min }$ are increasing with DTR for five stations increasing while the rest decreasing. We find a moderate decreasing trend for summer DTR over the deserts (Figure 17) in the range of 0.026 to $0.382^{\circ} \mathrm{C} /$ decade. The summer $\mathrm{T}_{\max }$ is increasing (Figure 18) as well in the range of 0.369 to $0.723^{\circ} \mathrm{C} /$ decade and on average $0.55^{\circ} \mathrm{C} /$ decade. The summer $\mathrm{T}_{\min }$ is also increasing sharply over the period $1985-2010$ in the range of 0.28 to $0.94^{\circ} \mathrm{C} /$ decade and on average $0.536^{\circ} \mathrm{C} /$ decade (Figure 19). 
Citation: Mugume I, Shen S, Tao S, Mujuni G (2016) Analysis of Temperature Variability over Desert and Urban Areas of Northern China. J

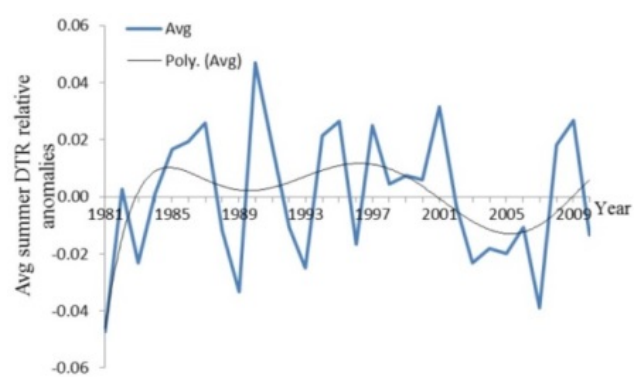

Figure 17: Summer DTR anomalies for selected desert areas.

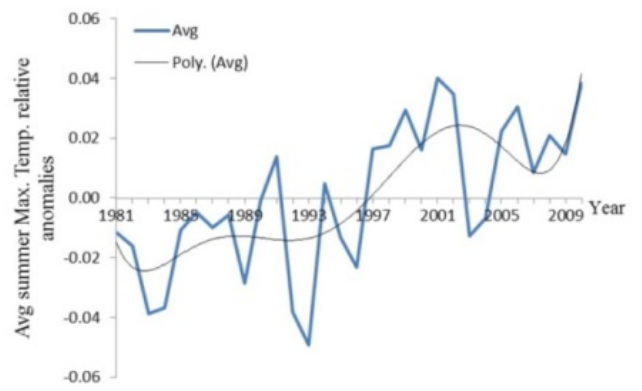

Figure 18: Summer maximum temperature anomalies for selected desert areas.

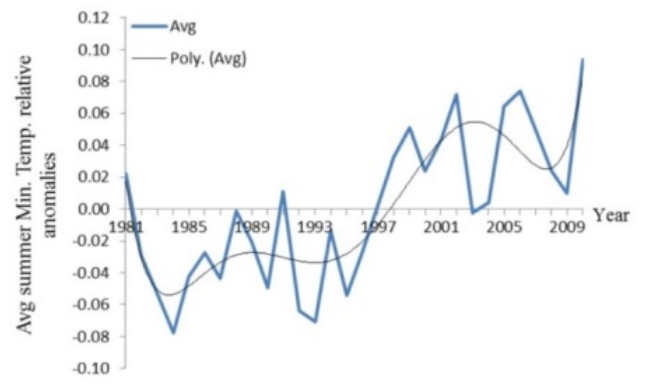

Figure 19: Summer minimum temperature anomalies for selected desert areas.

Over cities, we find increasing trends of summer $\mathrm{T}_{\max }$ and $\mathrm{T}_{\min }$ except Shenyang's $\mathrm{T}_{\min }$ and decreasing trend of DTR $\left(\mathrm{MK}_{\mathrm{z}}=-0.109\right)$ (Figure 20). The trend of summer DTR is in the range of -0.419 to $-0.023^{\circ} \mathrm{C} /$ decade and on average decreasing at a rate of $-0.140^{\circ} \mathrm{C} /$ decade. The summer $\mathrm{T}_{\max }$ (Figure 21 ) is increasing over the period $1991-2010$ in the range of 0.107 to $0.684^{\circ} \mathrm{C} /$ decade and in general, at a rate of $0.389^{\circ} \mathrm{C} /$ decade. From 1993 , the summer $\mathrm{T}_{\min }$ is also increasing (Figure 22) with exception of Shenyang in the range of 0.144 to $0.864^{\circ} \mathrm{C} /$ decade and in general increasing at $0.529^{\circ} \mathrm{C} /$ decade. Thus the rate of increase of $\mathrm{T}_{\min }\left(0.529^{\circ} \mathrm{C} /\right.$ decade $)$ is greater than that of $\mathrm{T}_{\max }$ $\left(0.389^{\circ} \mathrm{C} /\right.$ decade $)$ explaining the decreasing trend of DTR.

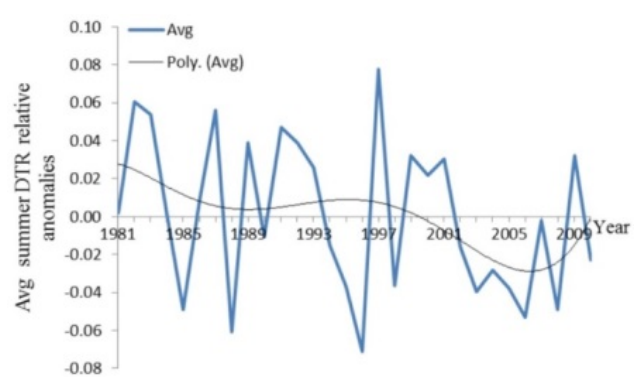

Figure 20: Summer DTR anomalies for selected cities.

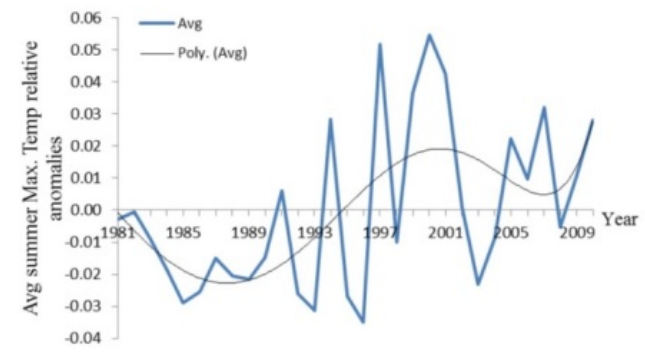

Figure 21: Summer maximum temperature anomalies for selected cities.

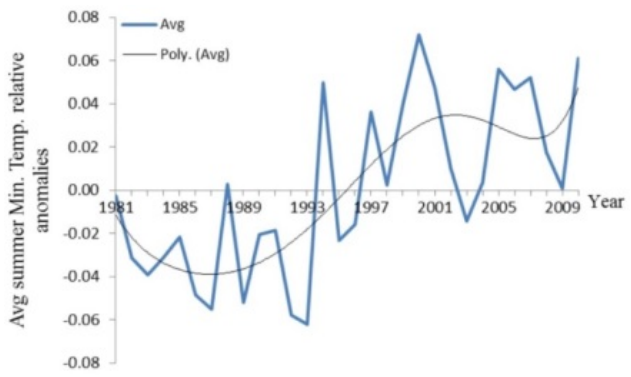

Figure 22: Summer minimum temperature anomalies for selected cities.

\section{High temperature days and high temperature extremes}

The Table 7 presents the trend of high temperature days and high temperature extreme days over desert areas during summer. The number of high temperature days, with exception of DaQaidam is increasing for all the stations $\left(\mathrm{MK}_{\mathrm{z}}=0.151\right.$ to 0.492$)$ as well as the days having high temperature extremes $\left(\mathrm{MK}_{\mathrm{z}}=0.159\right.$ to 0.493$)$. The highest temperature for Da-Qaidam was below $35^{\circ} \mathrm{C}$ and thus has the smallest rate of high temperature extremes.

\begin{tabular}{|l|l|l|}
\hline Area & High Temp. Days & High Temp. Extremes \\
\hline Alza Zuoqi & 0.250 & 0.493 \\
\hline Bayn MOD & 0.338 & 0.440 \\
\hline Da-Qaidam & N/A & 0.159 \\
\hline
\end{tabular}


Citation: Mugume I, Shen S, Tao S, Mujuni G (2016) Analysis of Temperature Variability over Desert and Urban Areas of Northern China. J

Page 8 of 9

\begin{tabular}{|l|l|l|}
\hline Guaizhu & 0.464 & 0.426 \\
\hline Hami & 0.492 & 0.445 \\
\hline Hoboksar & 0.151 & 0.308 \\
\hline Linhe & 0.189 & 0.328 \\
\hline Qiemo & 0.363 & 0.300 \\
\hline Ruoqiang & 0.509 & 0.339 \\
\hline Turpan & 0.386 & 0.353 \\
\hline Average & 0.349 & 0.326 \\
\hline
\end{tabular}

Table 7: Trend of high temperature days and high temperature extremes for desert areas.

The Table 8 shows the trend of high temperature days and high temperature extremes for selected cities. Like for the desert areas (Table 7), both the number of high temperature days is increasing for all the cities $\left(\mathrm{MK}_{\mathrm{z}}=0.140\right.$ to 0.511$)$ and the number of days with high temperature extremes $\left(\mathrm{MK}_{\mathrm{z}}=0.105\right.$ to 0.442$)$.

\begin{tabular}{|l|l|l|}
\hline Area & High Temp. Days & High Temp. Extremes \\
\hline Beijing & 0.283 & 0.343 \\
\hline Changchun & 0.314 & 0.138 \\
\hline Dalian & 0.179 & 0.105 \\
\hline Datong & 0.505 & 0.321 \\
\hline Harbin & 0.269 & 0.307 \\
\hline Hohhot & 0.289 & 0.303 \\
\hline Shenyang & 0.14 & 0.02 \\
\hline Taiyuan & 0.511 & 0.442 \\
\hline Tangshan & 0.242 & 0.307 \\
\hline Tianjin & 0.252 & 0.327 \\
\hline Average & 0.298 & 0.261 \\
\hline
\end{tabular}

Table 8: Trend of high temperature days and high temperature extremes for cities.

\section{Frost days and low temperature extremes}

The Table 9 shows the trend of frost days and days for low temperature extreme over spring for desert areas. We find both the frost days $\left(\mathrm{MK}_{\mathrm{z}}=-0.414\right.$ to -0.128$)$ and the number of days with extreme low temperatures $\left(\mathrm{MK}_{\mathrm{z}}=-0.446\right.$ to -0.010$)$ decreasing with a positive correlation of 0.614 . This decreasing trend means that few and fewer days have minimum temperature below zero degrees Celsius $\left(0^{\circ} \mathrm{C}\right)$. The Table 10 shows the trend of frost days and days for low temperature extreme over spring for cities.

\begin{tabular}{|l|l|l|}
\hline Area & Frost Days & Low Temp. Extremes \\
\hline Alza Zuoqi & -0.335 & -0.209 \\
\hline Bayan MOD & -0.128 & -0.01 \\
\hline
\end{tabular}

\begin{tabular}{|l|l|l|}
\hline Da-Qaidam & -0.355 & -0.05 \\
\hline Guaizhu & -0.375 & -0.222 \\
\hline Hami & -0.215 & -0.107 \\
\hline Hoboksar & -0.379 & -0.094 \\
\hline Linhe & -0.383 & -0.446 \\
\hline Qiemo & -0.155 & -0.054 \\
\hline Ruoqiang & -0.414 & -0.242 \\
\hline Turpan & -0.339 & -0.125 \\
\hline Average & 0.308 & 0.156 \\
\hline
\end{tabular}

Table 9: Trend of frost days and low temperature extremes for desert areas.

\begin{tabular}{|l|l|l|}
\hline Area & Frost Days & Low Temp. Extremes \\
\hline Beijing & -0.125 & -0.304 \\
\hline Changchun & -0.133 & -0.381 \\
\hline Dalian & -0.231 & -0.148 \\
\hline Datong & -0.334 & -0.311 \\
\hline Harbin & -0.272 & -0.442 \\
\hline Hohhot & -0.324 & -0.29 \\
\hline Shenyang & 0.021 & 0.319 \\
\hline Taiyuan & -0.362 & -0.389 \\
\hline Tangshan & -0.272 & -0.184 \\
\hline Tianjin & -0.08 & 0.01 \\
\hline Average & -0.237 & -0.308 \\
\hline
\end{tabular}

Table 10: Trend of frost days and low temperature extremes for cities.

Like deserts, the cities show a decreasing trend of both frost days $\left(\mathrm{MK}_{\mathrm{z}}=-0.362\right.$ to -0.080$)$ and the number of days having extreme low temperature $\left(\mathrm{MK}_{\mathrm{z}}=-0.442\right.$ to -0.148$)$ with a positive correlation of 0.730 . The decreasing trend means that few and fewer days have $T_{\min }$ below zero degrees Celsius $\left(0^{\circ} \mathrm{C}\right.$. $)$ and it also explains the increase of spring $\mathrm{T}_{\mathrm{min}}$. We find a greater decrease of frost days for desert greater than the rate for the cities which probably indicates that spring night are becoming warmer for deserts at a faster rate compared to cities.

\section{Summary and Conclusion}

In the present study, we investigated the variability of temperature over desert and cities of Northern China for the period 1981-2010. We found DTR decreasing for both desert and cities. It is evident that the DTR for cities is decreasing faster than the desert's. The $T_{\max }$ is increasing for both desert and cities and that $\mathrm{T}_{\max }$ for the deserts is increasing faster than that for the cities. The $\mathrm{T}_{\min }$ is increasing as well for both deserts and cities and the rate of increase of $\mathrm{T}_{\min }$ for the desert greater than the one for cities. 
Citation: Mugume I, Shen S, Tao S, Mujuni G (2016) Analysis of Temperature Variability over Desert and Urban Areas of Northern China. J

Page 9 of 9

We also find both the deserts and cities exhibiting an increasing trend of high temperature days and high temperature extremes. The rate of increase of high temperature extremes over deserts is slightly higher than the one over cities. In general, the summer $\mathrm{T}_{\max }$ for all the areas show increasing trend. The frost days and low temperature extremes over both the deserts and cities are decreasing. The frost days over deserts decrease slightly higher than over cities and in general, the spring $\mathrm{T}_{\min }$ for all the stations is increasing explaining the decreasing trend of the frost days and low temperature extremes.

\section{Acknowledgement}

This study is supported by the Research Fund for the Public Sector of China (GYHY201506018) and the Climate Change Specific Foundation of China Meteorological Administration (CCSF201318). The authors also acknowledge expert opinion from reviewers in quest of improving our manuscript.

\section{References}

1. Zabeltitz CV, Baudoin WO (1999) Greenhouses and shelter structures for tropical regions. Food and Agriculture Org 154.

2. Ahrens DC (2011) Essentials of meteorology: an invitation to the atmosphere. Cengage Learning.

3. Bryan JB, Konstantin YV, Russell RD (2010) Changes in seasonal and diurnal cycles of ozone and temperature in the eastern US. Atmospheric Environment 44: 2543-2551.

4. Walter JS (1989) Principles of meteorological analysis. Courier Corporation.

5. Boko M (2012) Managing the Risks of Extreme Events and Disasters to Advance Climate Change Adaptation. A Special Report of Working Groups I and II of the Intergovernmental Panel on Climate Change.

6. Wang K, Ye H, Chen F, Xiong Y, Wang C (2012) Urbanization effect on the diurnal temperature range: different roles under solar dimming and brightening. Journal of Climate 25: 1022-1027.

7. Schmal H (1981) Patterns of European urbanisation since 1500309.

8. Richard B, Arnell NW, Adger WN, Thomas D (2013) Migration, immobility and displacement out- comes following extreme events. Environmental Science and Policy 27: S32-43.

9. Easterling DR, Evans JL (2000) Observed variability and trends in extreme climate events: A brief review. Bulletin of the American Meteorological Society 81: 417-425.

10. Roy S, Shouraseni, Yuan F (2009) Trends in extreme temperatures in relation to urbanization in the Twin Cities Metropolitan Area, Minnesota. Journal of Applied Meteorology and Climatology 48: 669-679.
11. Selvaraju, Ramamasy, Baas S (2007) Climate Variability and Change: Adaptation to Drought in Bangladesh: a Resource Book and Training Guide 9.

12. Sailor, David J (1993) Role of surface characteristics in urban meteorology and air quality. Lawrence Berkeley Lab, CA.

13. Thomas PC, Stott PA, Stephanie H (2012) Explaining extreme events of 2011 from a climate perspective. Bulletin of the American Meteorological Society 93: 1041-1067.

14. Oerlemans, Johannes (2001) Glaciers and climate change. CRC Press.

15. Timothy MK (2010) Climate change: shifting glaciers, deserts, and climate belts. Infobase Publishing.

16. Tao S, Shen S, Li Y, Wang Q, Gao P, Mugume I (2016) Projected Crop Production under Regional Climate Change Using Scenario Data and Modeling: Sensitivity to Chosen Sowing Date and Cultivar. Sustainability 8: 214.

17. Jaswal AK, Rao PCS, Singh V (2015) Climatology and trends of summer high temperature days in India during 1969-2013. Journal of Earth System Science 124: 1-15.

18. Watson RT, Zinyowera MC, Moss RH (1998) The regional impacts of climate change: an assessment of vulnerability. Cambridge University Press.

19. Uddin AJ (2007) Industrialisation in North-Eastern Region. Mittal Publications.

20. Rooij V, Benjamin (2006) Regulating land and pollution in China: law making, compliance, and enforcement: theory and cases. Amsterdam University Press.

21. Zhou L, Dickinson RE, Tian Y (2004) Evidence for a significant urbanization effect on climate in China. Proceedings of the National Academy of Sciences of the United States of America 101: 9540-9544.

22. Qiang Z, Vijay PS, Suna P, Chend X (2011) Precipitation and stream flow changes in China: changing patterns, causes and implications. Journal of Hydrology 410: 204-216.

23. Jagannathan P, Parthasarathy B (1973) Trends and periodicities of rainfall over India. Monthly Weather Review 101: 371-375.

24. Jenkinson AF (1977) The analysis of meteorological and other geophysical extremes. Met Office Synoptic Climatology Branch Memo 58: 41.

25. Chris F, Anderson C (2002) Estimating changing extremes using empirical ranking methods. Journal of climate 20: 2954-2960.

26. Bonsal BR, Zhang X, Vincent LA (2001) Characteristics of daily and extreme temperatures over Canada. Journal of Climate 14: 1959-1976. 